\title{
INVESTIGATION OF SYMMETRIC AND ASYMMETRIC CAUSALITY OF KNITTED GARMENT FOREIGN TRADE BETWEEN TURKEY AND GERMANY
}

Dr. Öğr. Üye. Yusuf ESMER*

Dr. Öğr. Üye. Ahmet ÖZBEK***

Dr. Öğr. Üye. Mustafa KIRCA*+*

\begin{abstract}
Turkey and Germany are the two most important exporters of knitted garments in the world. Germany is also an important knitted garment export market for Turkey. In this respect, knitted garment trade between Germany and Turkey has a strategic importance that should be managed strategically. Therefore, determining the causality of knitted garment trade between Turkey and Germany will contribute to the strategic management of foreign trade. The aim of this study is to determine the symmetric and asymmetric causality of knitted garment trade between Turkey and Germany using the two countries' knitted garment export data. Results show that changes in Turkey's knitted garment export affects Germany's knitted garment export but that changes in Germany's knitted garment export does not lead to a change in Turkey's export. This result indicates that knitted garment trade between Germany and Turkey is more advantageous for Turkey and confirms that Germany is an important knitted garment export market for Turkey. On the other hand, the top 5 countries that Turkey exports most knitted garment products are Germany, United Kingdom, Spain, Iraq and Holland while the top 5 countries that Germany exports most knitted garment products are Switzerland, Austria, France, Holland and Poland. In conclusion, we believe that the results of this study will provide foreign trade managers with important information on the strategic management of knitted garment foreign trade.
\end{abstract}

Keyword: Knitted Garment Export, Foreign Trade, Strategic Management of Foreign Trade, Causality, Turkey, Germany

\section{TÜRKIYE ILE ALMANYA ARASINDAKI ÖRME HAZIR GIYYM DIŞ TICARETININ SIMETRIK VE ASIMETRIK NEDENSELLIK ILIŞKILERININ INCELENMESi}

\section{ÖZ}

Türkiye ve Almanya, dünyanın örme hazır giyim ürünü ihraç eden en önemli ülkeler arasındadır. Ayrıca Almanya, Türkiye için örme hazır giyim ürün ihracatında en önemli bir pazar durumundadır. Bu yönüyle Türkiye ile Almanya arasındaki örme hazır giyim ihracatı stratejik bir öneme sahiptir ve bu yönüyle stratejik yönetilmesi gerekmektedir. Bu nedenle Türkiye ile Almanya arasındaki örme hazır giyim ticaretinin nedensellik ilişkilerinin tespit edilmesi dış ticaretin stratejik yönetimine katkı sağlayacaktır. Bu çalışmada Türkiye ve Almanya'nın örme hazır giyim ihracat verileri kullanılarak iki ülke arasındaki örme hazır giyim ticaretinin simetrik ve asimetrik nedensellik ilişkileri tespit edilmeye çalışılmaktadır. Araştırma sonucuna göre Türkiye'nin örme hazır giyim ihracatındaki değişimlerinin, Almanya'nın örme hazır giyim ihracatını etkilemekte olduğu fakat Almanya'nın örme hazır giyim ihracatındaki değişimlerin Türkiye'nin ihracatında bir değişime neden olmadığı sonucuna ulaşılmıştır. Bu sonuç Türkiye ve Almanya arasında gerçekleşen örme hazır giyim ürünleri ticaretinde daha çok Türkiye 'nin lehine bir durumun olduğunu göstermekte ayrıca bu sonuç Almanya`nın Türkiye için önemli bir örme

\footnotetext{
*Bayburt Üniversitesi Uygulamalı Bilimler Fakültesi, Yönetim Bilişim Sistemleri, yesmer@bayburt.edu.tr, ORCID No: 0000-0003-3691-1730

*Marmara Üniversitesi Teknoloji Fakültesi, Tekstil Yönetim ve Pazarlama, aozbek@marmara.edu.tr, ORCID No: 0000-0001-5015-8082

*Düzce Üniversitesi/ Akçakoca Bey Siyasal Bilgiler Fakültesi, mustafakirca52@gmail.com, ORCID No: 0000-0002-5630-7525
} 
hazır giyim pazarı olduğunu doğrulamaktadır. Ayrıca Türkiye'nin en fazla örme hazır giyim ürünü ihraç ettiği 5 ülke sırasıyla; Almanya, Birleşik Krallık, İspanya, Irak ve Hollanda iken Almanya'nın en çok ihracat yaptığı 5 ülke ise İsviçre, Avusturya, Fransa, Hollanda ve Polonya'dır. Sonuç olarak bu çalışmadan elde edilen bulguların örme hazır giyim dış ticaretinin stratejik yönetimi bağlamında dış ticaret yöneticilerine önemli bilgiler sağlayacağı düşünülmektedir.

Anahtar Kelimeler: Örme Hazır Giyim İhracatı, Dış Ticaret, Dış Ticaretin Stratejik Yönetimi, Nedensellik Illişkisi, Türkiye, Almanya

\section{Introduction}

Globalization can be defined as countries' economic, social and political integration (Dogan and Can, 2016), the most important of which is, undoubtedly, economic integration (Agcakaya and Ogrekci, 2016). The aim of economic integration is the integration of the economies of the countries with the world economy by ensuring the flow of goods, services, labor and capital across countries or increasing the global trade and welfare by turning national markets into one single market. Foreign trade is, therefore, most affected by globalization (Gultekin and Uyumez, 2015; Metin and Akcan, 2017). Foreign trade is the commercial activity of countries with others in order to sell their surplus products with a high profit margin and to obtain products that they cannot produce with their own resources or produce at high cost (Metin and Akcan, 2017; Erturk, 2017). These activities not only help countries to maintain their economic growth and development but also lead to intense competition among countries (Kapkara and Koc, 2016).

Clothing is one of the most essential needs of human beings. The ready-made garment industry has emerged to meet this need. Since the beginning of the $21 \mathrm{st}$ century, developing and underdeveloped countries have invested heavily in the readymade garment sector as they considered it a source of employment and a transition to heavy industry. These investments have led to the globalization of and increased competition in the ready-made garment sector (Ozbek and Akalin, 2009) because costs in the international garment trade have been the most important means of competition. Ready-made garment products in international trade consist of three groups: knitted, unknitted and other ready-made garments. The cost of knitted ready-made garments is lower than that of woven ready-made garments because fabric is the highest cost item (about $50 \%$ ) in ready-made garment production, and, therefore, woven fabrics are costlier than knitted fabrics. In addition, knitted garments are more widely used (socks, underwear, pajamas, pullovers, T-shirts) and produced more than woven products.

The knitted garment export industry is worth an estimated 225 billion USD in the world. The data of the knitted garment exporter countries are given in Table 1. 70.5\% of knitted garments are exported by the top ten countries. China is the biggest exporter while Turkey is the fifth and Germany is the fourth.

Table 1: Global Knitted Garment and Accessories Export (1000 USD)

\begin{tabular}{|l|l|l|}
\hline Exporting Countries & 2017 & $\%$ \\
\hline China & 71.972 .535 & 31.87 \\
\hline Bangladesh & 17.921 .731 & 7.94 \\
\hline
\end{tabular}




\begin{tabular}{|l|l|l|}
\hline Vietnam & 13.091 .515 & 5.80 \\
\hline Germany & 9.974 .203 & 4.42 \\
\hline Turkey & 8.849 .652 & 3.92 \\
\hline Italy & 8.717 .723 & 3.86 \\
\hline India & 8.347 .381 & 3.70 \\
\hline Cambodia & 7.808 .435 & 3.46 \\
\hline Hong Kong & 7.094 .399 & 3.14 \\
\hline Spain & 5.421 .482 & 2.40 \\
\hline Other Countries & 66.615 .320 & 29.50 \\
\hline Total & 225.814 .376 & 100.00 \\
\hline
\end{tabular}

Source: Trade Map, 2017

Turkey exported only cotton and cotton fabrics to the world until the $1980 \mathrm{~s}$. It, however, began to implement a policy of liberalization in foreign trade in the 1980s and, thus, has become one of the biggest ready-made garment exporters in the world (Ozbek, 2018).

Today, the Turkish ready-made garment sector accounts for about 11 percent of the country's total export earnings and is one of the sectors with the highest export and net foreign exchange input within the manufacturing industry (URAGEM, 2016; Sat Sezgin, 2017). According to TSI 2016 data, the knitted garment sector has the third largest share of Turkey's exports (TUIK, 2017). Turkey's knitted garment export data are given in Table 2. The largest market for Turkey's knitted garment exports is Germany (21.7\%) followed by The United Kingdom and Spain.

Table 2: Turkey's Knitted Garment and Accessories Export (1000 USD)

\begin{tabular}{|l|l|l|}
\hline Importing Countries & $\mathbf{2 0 1 7}$ & $\%$ \\
\hline United Kingdom & 1.268 .462 & 14.33 \\
\hline Spain & 866.097 & 9.79 \\
\hline Iraq & 451.780 & 5.11 \\
\hline Holland & 445.964 & 5.04 \\
\hline France & 445.217 & 5.03 \\
\hline Italy & 285.279 & 3.22 \\
\hline Poland & 233.758 & 2.64 \\
\hline Belgium & 204.606 & 2.31 \\
\hline Denmark & 178.166 & 2.01 \\
\hline Other Countries Total & 2.549 .744 & 28.81 \\
\hline World Total & 8.849 .652 & 100.00 \\
\hline
\end{tabular}

Source: Trade Map, 2017 
Germany's knitted garment export data are given in Table 3. The markets for Germany's knitted garment exports are Switzerland, Austria and France.

Table 3: Germany's Knitted Garment and Accessories Export (1000 USD)

\begin{tabular}{|l|l|l|}
\hline Importing Countries & 2017 & $\%$ \\
\hline Switzerland & 1.381 .366 & 13.85 \\
\hline Austria & 1.354 .925 & 13.58 \\
\hline France & 1.056 .177 & 10.59 \\
\hline Holland & 1.007 .535 & 10.10 \\
\hline Poland & 671.021 & 6.73 \\
\hline United Kingdom & 635.172 & 6.37 \\
\hline Italy & 519.823 & 5.21 \\
\hline Belgium & 472.801 & 4.74 \\
\hline Spain & 379.662 & 3.81 \\
\hline Slovakia & 289.838 & 2.91 \\
\hline Other Countries & 2.205 .883 & 22.12 \\
\hline World Total & 9.974 .203 & 100.00 \\
\hline Source: Trade Map, 2017 & &
\end{tabular}

Source: Trade Map, 2017

Germany's knitted garment import data are given in Table 4. Germany imports knitted garment products from China, Bangladesh and Turkey the most. Germany's knitted garment export and import data also show that Germany re-exports half of its imported products. Therefore, Germany is both an important exporter and importer of knitted garment products.

Table 4: Germany's Knitted Garment and Accessories Import (1000 US \$)

\begin{tabular}{|l|l|l|}
\hline Importing Countries & $\mathbf{2 0 1 7}$ & $\%$ \\
\hline China & 4.428 .636 & 23.33 \\
\hline Bangladesh & 3.255 .610 & 17.15 \\
\hline Turkey & 2.367 .785 & 12.47 \\
\hline Cambodia & 987.411 & 5.20 \\
\hline Italy & 903.752 & 4.76 \\
\hline India & 878.214 & 4.63 \\
\hline Netherlands & 624.874 & 3.29 \\
\hline Vietnam & 401.788 & 2.02 \\
\hline Pakistan & 383.349 & 2.02 \\
\hline France & 343.920 & 1.81 \\
\hline Other Countries Total. & 4.408 .410 & 23.22 \\
\hline World Total & 18.983 .749 & 100.00 \\
\hline
\end{tabular}


Source: Trade Map, 2017

The aim of this study is to determine the symmetric and asymmetric causality of knitted garment trade between Turkey and Germany using the two countries' knitted garment export data. We believe that results will provide foreign trade managers with important information on the strategic management of foreign trade.

\section{Literature}

This section examined studies on Turkey's bilateral trade relations with other countries and addressed studies on foreign trade relations especially with Germany. Some of these studies are given in Table 5.

Table5: Literature Review

\begin{tabular}{|c|c|}
\hline Researcher & Methods and Results \\
\hline $\begin{array}{l}\text { Bashimov } \\
(2018)\end{array}$ & $\begin{array}{l}\text { The foreign trade between Turkey and Iran was investigated using } \\
\text { sectoral concentration, Gini-Hirschman index on comparative } \\
\text { advantage and intra-industry trade, Balassa's Revealed Comparative } \\
\text { Advantage Index and the Grubel-Lloyd index. Sectoral concentration } \\
\text { in Turkey's exports to Iran has decreased. Turkey has a comparative } \\
\text { advantage in } 14 \text { commodity groups and the intra-industry trade level } \\
\text { between the two countries is generally low. }\end{array}$ \\
\hline $\begin{array}{l}\text { Ersungur et } \\
\text { al. (2017) }\end{array}$ & $\begin{array}{l}\text { Turkey's trade relations with Germany, Russia and China were } \\
\text { examined using input-output analysis of } 1995,2000,2005,2008 \text { and } \\
2011 \text { data of key industries. Conditions for an import-dependent } \\
\text { production model have emerged for Turkey. This is not the case for } \\
\text { other countries. Being a foreign-dependent country in terms of } \\
\text { imported inputs is a big problem for Turkey as it reduces domestic } \\
\text { dependence for key industries. }\end{array}$ \\
\hline Kaweili (2017) & $\begin{array}{l}\text { The last } 15 \text { years of foreign trade between Turkey and China were } \\
\text { theoretically examined. Turkey has } 20 \text { billion USD annual trade deficit } \\
\text { with China. Anti-dumping practices applied to products imported from } \\
\text { China is the biggest problem of bilateral trade. }\end{array}$ \\
\hline $\begin{array}{l}\text { Kalayci } \\
(2017)\end{array}$ & $\begin{array}{l}\text { Revealed Comparative Advantage Index-RCA was used to determine } \\
\text { whether Turkey has a comparative advantage in foreign trade with } \\
\text { FTA countries in the 2012-2016 period. Turkey has a comparative } \\
\text { advantage in "live animals and foodstuffs," "beverages and tobacco" } \\
\text { and "miscellaneous manufactured articles" while it has no comparative } \\
\text { advantage in "raw materials other than fuel not used as food," "animal } \\
\text { and vegetable fat and oil and wax" and "chemical and industrial } \\
\text { products not specified." }\end{array}$ \\
\hline $\begin{array}{l}\text { Ozmen and } \\
\text { Firikci (2016) }\end{array}$ & $\begin{array}{l}\text { Turkey's export trend with Germany within the scope of the Customs } \\
\text { Union agreement was examined. Engle - Granger co-integration test } \\
\text { and Johansen co-integration test and Granger causality were used for }\end{array}$ \\
\hline
\end{tabular}




\begin{tabular}{|c|c|}
\hline & $\begin{array}{l}\text { analysis. After the Customs Union Agreement, the total volume of } \\
\text { foreign trade between the two countries has increased. It has, } \\
\text { however, changed the trade balance to the detriment of Turkey. }\end{array}$ \\
\hline $\begin{array}{l}\text { Akca et al. } \\
\text { (2016) }\end{array}$ & $\begin{array}{l}\text { Economic relations between Germany and Turkey were studied using } \\
\text { PESTEL analysis. Economic relations between Turkey and Germany } \\
\text { have enjoyed a high rate of growth in the energy and tourism sectors. } \\
\text { Turkey, however, needs markets other than Germany to increase its } \\
\text { trade volume. In addition, the balance of foreign trade between the } \\
\text { two countries is in favor of Germany. }\end{array}$ \\
\hline Zengin (2015) & $\begin{array}{l}\text { Trade relations between Turkey and the Russian Federation were } \\
\text { theoretically examined. Turkey has an important position in the } \\
\text { Russian Federation's imports of fresh fruit and vegetable while the } \\
\text { Russian Federation has an important position in Turkey's imports of oil } \\
\text { and gas products. This result shows that Turkey and the Russian } \\
\text { Federation are interdependent in foreign trade. }\end{array}$ \\
\hline $\begin{array}{l}\text { Demirtas } \\
(2014)\end{array}$ & $\begin{array}{l}\text { Bilateral trade relations between Turkey and Germany were examined } \\
\text { using monthly data for the period 2002-2012. A boundary test } \\
\text { approach based on an Autoregressive Distributed Lag Model was } \\
\text { used as a co-integration test. The loss in real value of the Turkish Lira } \\
\text { has a positive and significant impact on Turkey's balance of trade with } \\
\text { Germany in the short and long term. The industrial production index, } \\
\text { which represents the income of both countries, has a favorable effect } \\
\text { on the foreign trade balance. }\end{array}$ \\
\hline $\begin{array}{l}\text { Karagoz } \\
(2011)\end{array}$ & $\begin{array}{l}\text { An extended gravity model based on the panel dataset of } 2000-2005 \\
\text { was used to investigate in what way the amount of migration from } \\
\text { Turkey to other countries affects Turkey's volume of trade with those } \\
\text { countries. Results show that there is a positive and strong correlation } \\
\text { between migration and trade. }\end{array}$ \\
\hline $\begin{array}{l}\text { Ceviker et al. } \\
(2010)\end{array}$ & $\begin{array}{l}\text { The size and nature of Turkey's foreign trade with Central Asian } \\
\text { countries were examined. Data covering the years from } 1999 \text { to } 2008 \\
\text { were used. Turkey's and Germany's foreign trade with Central Asian } \\
\text { countries were compared. Germany has a larger volume of foreign } \\
\text { trade with Central Asian countries than does Turkey. Germany imports } \\
\text { large amounts of crude oil from the region. Therefore, Turkey's } \\
\text { volume of foreign trade with Central Asian countries is relatively low. }\end{array}$ \\
\hline
\end{tabular}

\section{Data And Model}

This study investigates the relationship between Turkey's monthly exports of knitted garment (TUR) and Germany' exports of knitted garment (GER) between $2007 \mathrm{M} 04$ and 2017M03. The data of the variables were obtained from Trade Map (2017) database. The graphs of the variables are presented in Figure 1. The variables have a seasonal and breakable structure. Despite the seasonal structure, the variables were not seasonally adjusted. The reason for this is that the components of the variables were used when performing the Hatemi-j (2012) asymmetric causality test. 
Therefore, the effect of seasonal positive and negative shocks on the variables were not ignored. The relationships between the original values of these two variables can be modeled as follows:

$$
\begin{gathered}
G E R_{t}=\beta_{0}+\beta_{1} T U R_{t}+u_{t}(1) \\
\text { and } \\
T U R_{t}=\alpha_{0}+\alpha_{1} G E R_{t}+\varepsilon_{t}(2)
\end{gathered}
$$

The $\mathrm{t}$ indices in the above models indicate that the variables are time series. In model no $1, \beta_{0}$ is the constant term and $\beta_{1}$ is the slope coefficient, i.e., the coefficient that expresses the effect of the change in TUR on GER. Similarly, in model no $1, \alpha_{0}$ is the constant term and $\alpha_{1}$ is the slope coefficient, i.e., the coefficient that expresses the effect of the change in GER on TUR. $u_{t}$ and $\varepsilon_{t}$ are the error terms of the models.

Figure 1: Graphs of Original Variables
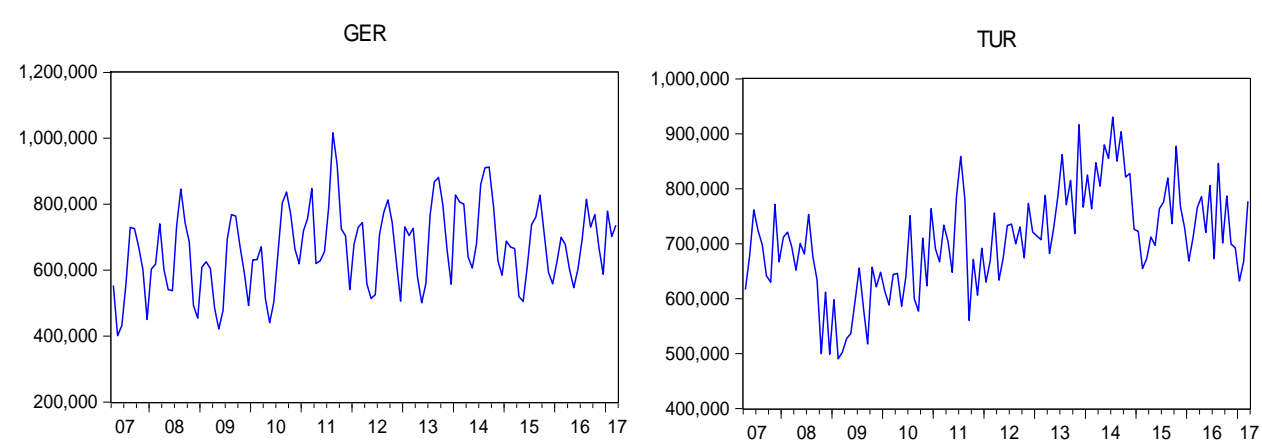

\section{Method and Findings}

Relationships between the variables were examined using Hacker and Hatemi-j (2006) symmetric, Hatemi-j (2012) asymmetric causality, and Hatemi-j (2011) asymmetric impulse-response function analyses.

It is an important condition to determine the order of stationarity of the two variables, which are time series, before examining the causality between them. The order of stationarity of the variables is important in Hacker and Hatemi-J (2006), Hatemi-j (2012) and Hatemi-j (2011) tests used in this study.

Hacker ve Hatemi-J (2006) and Hatemi-j (2012) causality tests are based on the causality test developed by Toda and Yamamoto (1995). However, as Hacker and Hatemi-j (2006) causality test is applied to original variables as in the Toda and Yamamoto (1995) causality test, these tests are referred to as symmetric causality tests. Hatemi-j (2012) causality test analyzes the causality between positive and negative shocks as does the co-integration test developed by Granger and Yoon, and therefore, the former is referred to as asymmetric causality test.

The causality test developed by Toda and Yamamoto (1995) does not have such conditions as the presence of a co-integration relationship between variables and variables being static in the same rank order. This test is, therefore, superior to other causality tests. Although it is not important in this test for variables to be static in the same rank order, the order of stationarity of variables should be determined because 
Toda and Yamamoto (1995) added the maximum degree of integration (dmax) to the model in order not to lose the long-term information of the variables. Toda and Yamamoto (1995) test the causality between variables using a Vector Autoregressive (VAR) ( $p+d m a x)$ model as follows:

$$
\left[\begin{array}{l}
G E R_{t} \\
T U R_{t}
\end{array}\right]=\varphi_{0}+\varphi_{1}\left[\begin{array}{c}
G E R_{t-1} \\
T U R_{t-1}
\end{array}\right]+\cdots+\varphi_{p+d_{\max }}\left[\begin{array}{c}
G E R_{t-p+d_{\max }} \\
T U R_{t-p+d_{\max }}
\end{array}\right]+w_{t}(3)
$$

In model no $3, \varphi_{0}$ is the constant term vector, $\varphi_{1} \ldots \varphi_{p+d m a x}$ are the parameter vectors and $w_{t}$ is the error term of the model. VAR models are models in which both the delays of the dependent variable and those of the independent variables are simultaneously included in the equality. An important issue in these models is the determination of the appropriate number of delays $(p)$. $P$ is determined using various information criteria and is expressed as $\operatorname{VAR}(p)$ model. $\operatorname{VAR}(\mathrm{p})$ model has to provide such conditions as lack of autocorrelation problem, lack of variance problem, and presence of stable coefficients. In Toda and Yamamoto (1995) and Hacker and Hatemi-j (2006) causality tests, dmax should also be determined. The dmax index in the above model represents the number of additional delays added to $\operatorname{VAR}(\mathrm{p})$ model and the model is in the form of VAR $(p+d m a x)$. dmax is determined testing the order of stationarity of the variables. For this, the unit root test is applied to both variables. Therefore, in this study, the order of stationarity of the variables were determined using the Augmented Dickey Fuller (ADF) unit root test, which takes into account structural breaks. The reason why a unit root test with structural break was used was that the variables had structural break points (Figure 1). Perron (1989) states that structural breaks should be considered in unit root tests. Table 6 shows the results of the ADF unit root test with one break.

Table 6: ADF Unit Root Test with One Break

\begin{tabular}{|l|c|c|l|c|l|l|}
\hline & \multicolumn{9}{|l|}{ Intercept } & \multicolumn{3}{l|}{ Intercept and Trend } \\
\hline Variables & $\begin{array}{l}\text { Test } \\
\text { Statistic }\end{array}$ & $\begin{array}{l}\text { Critical } \\
\text { Value }\end{array}$ & $\begin{array}{l}\text { Break } \\
\text { Date }\end{array}$ & $\begin{array}{l}\text { Test } \\
\text { Statistic }\end{array}$ & $\begin{array}{l}\text { Critical } \\
\text { Value }\end{array}$ & $\begin{array}{l}\text { Break } \\
\text { Date }\end{array}$ \\
\hline GER & $-8.056^{*}$ & -4.443 & $2007 \mathrm{M} 07$ & $-8.234^{*}$ & -5.175 & $2010 \mathrm{M} 07$ \\
\hline TUR & -2.931 & -4.443 & $2007 \mathrm{M} 08$ & -3.875 & -5.175 & $2007 \mathrm{M} 12$ \\
\hline DGER & - & - & - & - & - & - \\
\hline DTUR & $-19.276^{*}$ & -4.443 & $2007 \mathrm{M} 08$ & $-19.359^{*}$ & -5.175 & $2007 \mathrm{M} 09$ \\
\hline
\end{tabular}

* Stationarity at the significance level $\alpha=0.05$.

Table 6 shows that Although GER is I(0) for both "intercept" and "intercept and trend" specifications, TUR is I(1), indicating that GER is trend stationary while TUR is stationary in the first difference because the absolute test statistics values are greater than the absolute critical values at the significance level of 0.05 . Then the hypothesis that "the variable has unit root" is rejected. dmax was, therefore, determined as "1."

After the determination of VAR(p+dmax) model, Toda and Yamamoto (1995) and Hacker and Hatemi-j (2006) test the following hypothesis:

$H_{0}: \varphi_{1}=\varphi_{2}=\ldots=\varphi_{p}=0$, "GER does not Granger-cause TUR" or "TUR does not Granger-cause GER" 


\section{GER"}

$H_{1}$ : At least one $\varphi \neq 0$, "GER Granger-causes TUR" or "TUR Granger-causes

As in the Granger-causality test, Toda and Yamamoto (1995) apply a restriction test on parameter vectors in hypotheses to calculate a modified Wald statistic and test its statistical significance to decide on the hypotheses. This MWald test statistical value calculated according to Hacker and Hatemi-j (2006) shows $x 2$ distribution. However, in some cases, this assumption is not valid and the model may have the problem of heteroscedasticity. This is where the Hacker and Hatemi-j (2006) causality test differs from the Toda and Yamamoto (1995) causality test. Hacker and Hatemi-j (2006) use bootstrap method to overcome this problem and to obtain the critical values of the test they developed. This test is, therefore, superior to other causality tests. Because of this superiority, only the Hacker and Hatemi-J (2006) symmetric causality test was used to determine whether there was causality between the original variables in this study. Furthermore, $p=2$ was determined using the information criterion (HJC) developed by Hatemi-J, and $\mathrm{d}_{\max }=1$ was added to the model. Table 7 shows the Hacker and Hatemi-j (2006) causality test results.

Table 7: Hacker and Hatemi-J (2006) Causality Test Results

\begin{tabular}{|l|c|c|c|}
\hline \multicolumn{1}{|c|}{ Hypotheses } & $\begin{array}{c}\text { Test } \\
\text { Statistics }\end{array}$ & $\begin{array}{c}\mathbf{5 \%}^{\text {Critical }} \\
\text { Value }^{\star \star *}\end{array}$ & Lags $^{\star *}$ \\
\hline $\begin{array}{l}\text { TUR does not Granger-cause } \\
\text { GER }\end{array}$ & $18.721^{*}$ & 6.170 & 2 \\
\hline $\begin{array}{l}\text { GER does not Granger-cause } \\
\text { TUR }\end{array}$ & 2.389 & 6.066 & 2 \\
\hline
\end{tabular}

* Significance level $\alpha=0.05$

** Lag length is determined by HJC

Additional lags $=1$

*** Critical values were obtained using bootstrap

Table 7 shows that there is one-way causality from TUR to GER because the test statistic is greater than the critical value at the significance level of 0.05 , and therefore, the $\mathrm{HO}$ hypothesis is rejected. This indicates that Turkey's export of readymade garment has an effect on Germany's export of ready-made garment.

S stated earlier, the Hacker and Hatemi-J (2006) causality test considered positive and negative shocks to be the same and applied the causality test on original variables. However, Hatemi-J (2012) stated that there could be difference in causality between positive and negative shocks of variables, and therefore, developed an asymmetric causality test. For this purpose, he firstly divided the variables into positive and negative shocks ${ }^{1}$ and then applied the shocks to the causality test developed by Hacker and Hatemi-j (2006). In other words, the only difference between this test and the Hacker and Hatemi-j (2006) causality test is that the former performs the causality test using the shocks of variables. Figure 2 shows the graphs of the positive and negative shocks of the variables.

\footnotetext{
1 See Hatem-j (2012: 449) for detailed information on dividing variables into shocks (components)
} 
Figure 2: Graphs of Components of Variables ${ }^{2}$
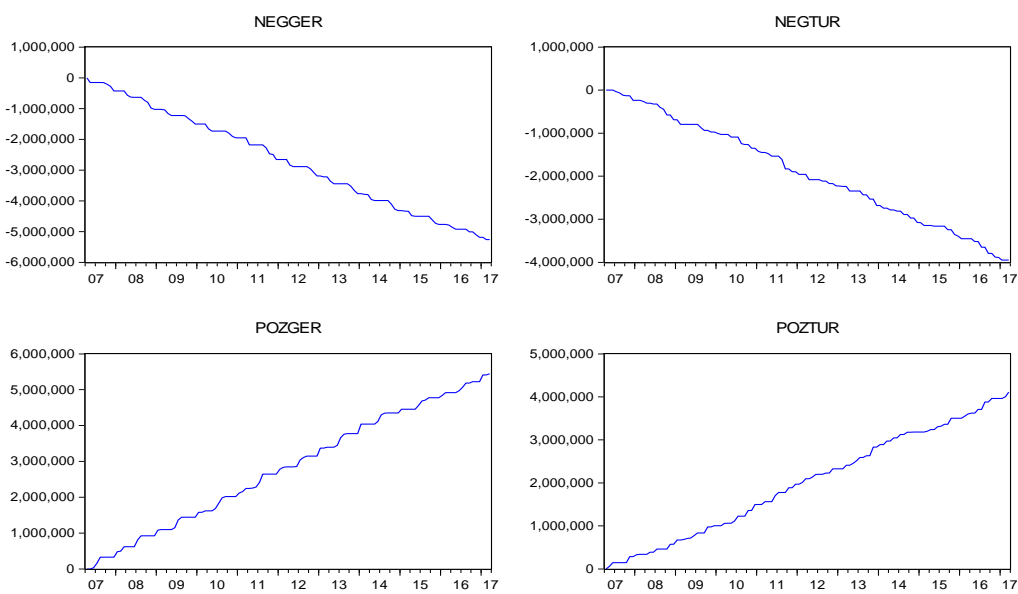

VAR model is used to show the relationship between the shocks. For example, the relationships between the positive shocks of the variables used in the study can be shown using a $\operatorname{VAR}(\mathrm{p})$ model as follows:

$$
\left[\begin{array}{c}
G E R_{t}^{+} \\
T U R_{t}^{+}
\end{array}\right]=\partial_{0}+\partial_{1}\left[\begin{array}{c}
G E R_{t-1}^{+} \\
T U R_{t-1}^{+}
\end{array}\right]+\cdots+\partial_{p}\left[\begin{array}{c}
G E R_{t-p}^{+} \\
T U R_{t-p}^{+}
\end{array}\right]+v_{t}(4)
$$

In model no 4, GER $R_{t}^{+}$is the positive shocks in Germany's export of ready-made garments and $T U R_{t}^{+}$is the positive shocks in Turkey's export of ready-made garments. Models can be derived for other relationships between the shocks as well. As in the case of Hacker and Hatemi-j (2006) causality test, Hatemi-J (2012) uses bootstrap to examine the causality between these positive and negative shocks and to obtain the critical values of interest. The following eight hypotheses can be tested using the Hatemi-j (2012) asymmetric causality test:

1. Null Hypothesis: There is no causality from $G E R_{t}^{+}$to $T U R_{t}^{+}$.

2. Null Hypothesis: There is no causality from $G_{E} R_{t}^{+}$to $T U R_{t}^{-}$.

3. Null Hypothesis: There is no causality from GER $R_{t}^{-}$to $T U R_{t}^{+}$.

4. Null Hypothesis: There is no causality from GER $R_{t}^{-}$to TUR $R_{t}^{-}$.

5. Null Hypothesis: There is no causality from $T U R_{t}^{+}$to $G E R_{t}^{+}$.

6. Null Hypothesis: There is no causality from $T U R_{t}^{+}$to $G E R_{t}^{-}$.

7. Null Hypothesis: There is no causality from $T U R_{t}^{-}$to $G E R_{t}^{+}$.

8. Null Hypothesis: There is no causality from $T U R_{t}^{-}$to $G E R_{t}^{-}$.

Prior to the Hatemi-j (2012) asymmetric causality test, the stationarity property of positive and negative shocks should be examined and the maximum integration level

\footnotetext{
${ }^{2}$ NEGGER is the negative shocks in Germany's export of ready-made garment (GER'); NEGTUR is the negative shocks in Turkey's export of ready-made garment (TUR'); POZGER is the positive shocks in Germany's export of ready-made garment $\left(G^{+} R^{+}\right)$; POZTUR is the positive shocks in Turkey's export of ready-made garment $\left(\mathrm{TUR}^{+}\right)$.
} 
$\left(d_{\max }\right)$ between the variables should be added to the model. Table 8 shows the ADF unit root test results of the shocks of the variables.

Table 8: ADF Unit Root Test Results of Components**

\begin{tabular}{|l|l|l|}
\hline Variables & Test Statistic & Probability \\
\hline GER $^{+}$ & -1.0615 & 0.9299 \\
\hline TUR $^{+}$ & -2.6266 & 0.2695 \\
\hline GER $^{-}$ & -1.6051 & 0.7847 \\
\hline TUR $^{-}$ & -3.0884 & 0.1139 \\
\hline$\Delta$ GER $^{+}$ & $-10.1340^{*}$ & 0.0001 \\
\hline$\Delta$ TUR $^{+}$ & $-15.4561^{*}$ & 0.0001 \\
\hline$\Delta$ GER $^{-}$ & $-10.0610^{*}$ & 0.0001 \\
\hline$\Delta$ TUR $^{-}$ & $-7.1643^{*}$ & 0.0001 \\
\hline
\end{tabular}

*Stationarity at the significance level $\alpha=0.05$.

**Unit root test was used considering Intercept and Trend Model.

Table 8 shows that all shocks are I (1), indicating that they are stationary in the first difference. In this case, $d_{\max }=1$ for the Hatemi-j (2012) asymmetric causality test. The HJC information criterion was used to determine the $p$ value. Table 9 shows the Hatemi-J (2012) asymmetric causality results. This test tests hypotheses the same way as does the Hacker and Hatemi-j (2006) causality test, which means that the HO hypothesis is rejected if the test statistic is greater than the critical value at the significance level of 0.05 . Table 9 shows that there is one-way causality from $\boldsymbol{T} \boldsymbol{U} \boldsymbol{R}_{t}^{+}$to $\boldsymbol{G E} \boldsymbol{R}_{\boldsymbol{t}}^{+}$, from $\boldsymbol{T} \boldsymbol{U} \boldsymbol{R}_{\boldsymbol{t}}^{-}$to $\boldsymbol{G} \boldsymbol{E} \boldsymbol{R}_{\boldsymbol{t}}^{-}$and from $\boldsymbol{T} \boldsymbol{U} \boldsymbol{R}_{t}^{+}$to $\boldsymbol{G E} \boldsymbol{R}_{\boldsymbol{t}}^{-}$. This indicates that there is asymmetric causality especially from the shocks of TUR to those of GER.

Table 9: Hatemi-J (2012) Asymmetric Causality Test Results

\begin{tabular}{|l|c|c|c|}
\hline Hypotheses & Test Statistics & $\begin{array}{c}\text { \%5 Critical } \\
\text { Value }\end{array}$ & Lags $^{\star *}$ \\
\hline $\begin{array}{l}T U R_{t}^{+} \text {does not Granger-cause } \\
G E R_{t}^{+}\end{array}$ & $9.355^{\star}$ & 6.437 & 2 \\
\hline $\begin{array}{l}T U R_{t}^{-} \text {does not Granger-cause } \\
G E R_{t}^{-}\end{array}$ & $8.769^{*}$ & 4.111 & 1 \\
\hline $\begin{array}{l}T U R_{t}^{-} \text {does not Granger-cause } \\
G E R_{t}^{+}\end{array}$ & 0.002 & 4.097 & 1 \\
\hline $\begin{array}{l}T U R_{t}^{+} \text {does not Granger-cause } \\
G E R_{t}^{-}\end{array}$ & $17.738^{\star}$ & 4.102 & 1 \\
\hline $\begin{array}{l}G E R_{t}^{+} \text {does not Granger-cause } \\
T U R_{t}^{+}\end{array}$ & 2.348 & 6.472 & 2 \\
\hline$G E R_{t}^{-}$does not Granger-cause & 1.337 & 4.057 & 1 \\
\hline
\end{tabular}




\begin{tabular}{|l|c|c|c|}
\hline$T U R_{t}^{-}$ & & & \\
\hline $\begin{array}{l}G E R_{t}^{-} \text {does not Granger-cause } \\
T U R_{t}^{+}\end{array}$ & 0.001 & 4.221 & 1 \\
\hline $\begin{array}{l}G E R_{t}^{+} \text {does not Granger-cause } \\
\text { TUR }\end{array}$ & 0.082 & 4.228 & 1 \\
\hline
\end{tabular}

* Significant by level is 0.05

Additional lags $=1$

${ }^{* *}$ Lag length is determined by HJC

The asymmetric impulse response functions developed by Hatemi-J (2011) were used to determine the direction of the causality (relationships) between the shocks. These functions are no different from the impulse response functions based on VAR model developed by Sims (1980). Hatemi-j (2011) developed an impulse response function analysis using the positive and negative shocks of variables, not the original ones. As is known, variables (shocks) to be included in VAR model should be stationary. For this reason, the impulse response functions of the variables were investigated depending on differences in I(1) shocks. P satisfying the assumptions of VAR model was determined for VAR model equations estimated based on the differences. Let us first examine the result of the impulse response function for the oneway causality from $T U R_{t}^{+}$to $G E R_{t}^{-}$in Figure 3 .

Figure 3: Asymmetric impulse response function from $T U R_{t}^{+}$to $G E R_{t}^{-3}$

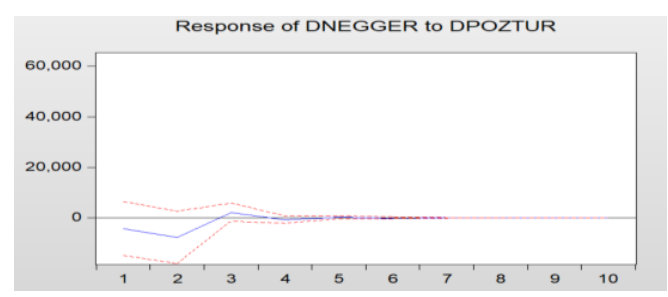

Figure 3 shows that the positive shock of Turkey's export of ready-made garments reduces the negative shock of Germany's export of ready-made garments. The effect of this reduction, however, continues for about 3 periods. Figure 4 shows the result of the impulse response function for the one-way causality from $T U R_{t}^{+}$to $G E R_{t}^{+}$.

Figure 4: Asymmetric impulse response function from $T U R_{t}^{+}$to $G E R_{t}^{+4}$

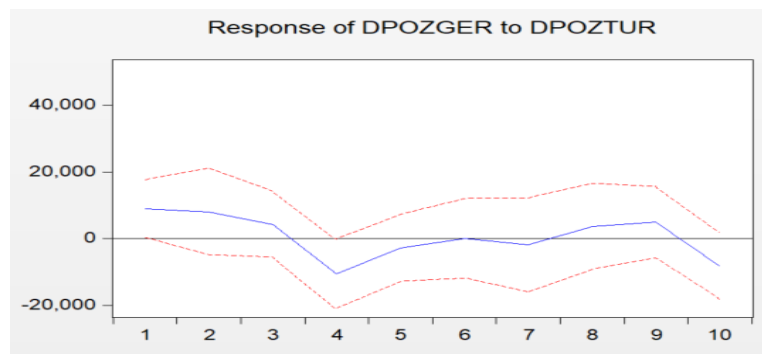

Figure 4 shows that the positive shock of Turkey's export of ready-made garments increases the positive shock of Germany's export of ready-made garments,

\footnotetext{
${ }^{3}$ VAR (1) model was used as it satisfied the requirements of VAR model.

${ }^{4}$ VAR (1) model was used as it satisfied the requirements of VAR model.
} 
and the effect of this increase continues for about 3 periods. Figure 5 shows the result of the impulse response function for the one-way causality from $T U R_{t}^{-}$to $G E R_{t}^{-}$.

Figure 5: Asymmetric impulse response function from $\mathrm{TUR}_{\mathrm{t}}^{-}$to $\mathrm{GER}_{\mathrm{t}}^{-5}$

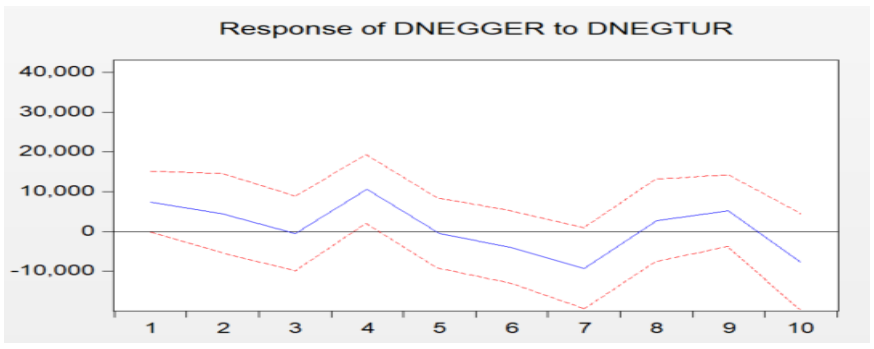

Figure 5 shows that the negative shock of Turkey's export of ready-made garments increases the negative shock of Germany's export of ready-made garments, and the effect of this increase continues for about 3 periods. The above results indicate that the changes in Turkey's export of ready-made garments affect Germany's export of ready-made garments. Germany is an important ready-made garment market for Turkey. Furthermore, Germany re-exports half the products it imports from Turkey. The results confirm this.

\section{Conclusion and Recommendations}

A good part of Turkey's main exports is knitted garment products. This study addressed the causality of knitted garment trade between Turkey and its most important trading partner, Germany. In this context, the aim of this study was to determine the symmetric and asymmetric causality of knitted garment trade between Turkey and Germany using knitted garment export data of the two countries. The results show that the changes in Turkey's export of ready-made garments affect Germany's export of ready-made garments. These results confirm that Germany is an important ready-made garment market for Turkey. Germany is of strategic significance for Turkey in terms of foreign trade and it is, therefore, recommended that necessary policies be developed in this regard. To this end, Turkish entrepreneurs should participate in big fairs in Germany and promote their products in order to increase Turkey's volume of exports to Germany (Akca et al., 2016). Turkey should also develop policies to gain competitive advantage and improve product quality and variety and take significant steps towards branding in order to increase Turkey's volume of exports to Germany (Ozmen and Firikci, 2016).

The top 5 countries that Turkey exports most knitted garment products are Germany, United Kingdom, Spain, Iraq and Holland while the top 5 countries that Germany exports most knitted garment products are Switzerland, Austria, France, Holland and Poland. The fact that Germany and Turkey operate in different markets, except for only Holland, allow both countries to increase their export volumes without having to compete with each other.

\footnotetext{
${ }^{5}$ VAR (10) model was used as it satisfied the requirements of VAR model.
} 
In conclusion, we believe that the results of this study will provide foreign trade managers with important information on the strategic management of knitted garment foreign trade.

\section{References}

AGCAKAYA, S., \& OGREKCI, S. (2016.) Globalization and The Universal Values Of Globalization. Suleyman Demirel University The Journal of Visionary, 7 (14), 25-42.

AKCA, H., SAHIN, L., \& Z. KAYA, Z. (2016). PESTEL Analizi ile Turkiye-Almanya Ekonomik Iliskilerinin Incelenmesi. Cankiri Karatekin Universitesi Sosyal Bilimler Enstitusu Dergisi, 7 (1), 323-334.

BASHIMOV, G. (2018). Turkiye ile Iran Arasindaki Ikili Ticaretin Analizi. Pamukkale Universitesi Sosyal Bilimler Enstitusu Dergisi, 30, 145-155.

CEVIKER, A., MUTLU, H.M., \& TAS, I. (2010). Turkiye'nin Orta Asya Ulkeleriyle Ticareti: Almanya ve Iran'la Karsilastimali Bir Analiz. International Conference on Eurasian Economies 2010, Istanbul.

DEMIRTAS, G. (2014). Turkiye ve Almanya Arasindaki Dis Ticaret Dengesinin Sinir Testi Yaklasimiyla Incelenmesi. Erciyes Universitesi Iktisadi ve Idari Bilimler Fakultesi Dergisi, 43, 83-106.

DOGAN, B., \& CAN, M. (2016). The Effect of Globalization on Growth: Cointegration Analysis for the Sample of South Korea. Cankiri Karatekin University Journal of The Faculty of Economics and Administrative Sciences, 6(2), 197-220.

ERSUNGUR, S. M., T. BAYRAMOGLU, T., \& H. PABUCCU, H. (2017). Turkiye'nin Almanya, Rusya ve Cin Ile Ticari lliskileri: Girdi-Cikti Analizi Ile Bir Uygulama. Gaziantep Universitesi Sosyal Bilimler Dergisi, 16(1), 252-267.

ERTURK, N. (2017). Trade Wars And Their Effects On World Economy. Fiscaoeconomia, 1(2), 88-112.

GRANGER, C.W., \& G. YOON, G. (2002). Hidden Cointegration. Discussion Paper, https://cloudfront.escholarship.org/dist/prd/content/qt9an5f61j/qt9an5f61j.pdf, date of acess: 27.05.2018.

GULTEKIN, R., \& UYUMEZ, M.E. (2015). Free Trade Agreement between Turkey end Russian Federation and its Possible Affects to These Countries' Tarde and Taxational Reflections. International Conference On Eurasian Economies 2015, Russia.

HACKER, R.S., \& HATEMI-J, A. (2006). Tests for Causality Between Integrated Variables: Using Asymptotic and Bootsrap Distributions: Theory and Application. Applied Economics, 38(13), 1489-1500.

HATEMI-J, A. (2011). Asymmetric Generalized Impulse Responses and Variance Decompositions with an Aplication. Munich Personal RePEc Archive, Paper No:31700, 1-8.

HATEMI-J, A. (2012). Asymmetric Causality Tests with an Application. Empirical Economics, 43(1), 447-456. 
KALAYCI, C. (2017). Serbest Ticaret Anlasmalarinin Turkiye'nin Dis Ticaretine Etkileri: Aciklanmis Karsilastirmali Ustunlukler Endeksi Uygulamasi. Uluslararasi Ekonomi ve Yenilik Dergisi, 3(2), 133-147.

KAPKARA, S., \& KOC, S. (2016). Gravity Model Analysis Of Trade Between Emerging Economies. Ege Academic Review, 16(3), 477-490.

KARAGOZ, K. (2011). Goc-Ticaret Iliskisi: Panel Cekim Modeli. Sosyo Ekonomi, Ozel Sayi, 56-68.

KAWEILI, P., \& ADIGUZEL, M. (2017). Turkiye Cin Dis Ticaretinin Incelenmesi. Tartisma Metinleri, Istanbul Ticaret Universitesi Dis Ticaret Enstitusu, Istanbul.

METIN, I,. \& A. T. AKCAN, A.T. (2017). The Effect of Globalization on Foreign Trade: Turkey Case. Journal of Current Researches on Business and Economics, 7(2), 257-268.

OZBEK, A. (2018). Turk Hazir Giyim Ticaretinin Alt Sektorler Bazında Analizi. Uluslararası Beseri Bilimler ve Egitim Dergisi, 4(7), 161-183.

Ozbek, A., \& AKALIN, M. (2009). Hazir Giyim Ihracatını Etkileyen Faktorler. Konfeksiyon Teknoloji Dergisi, 91, 68-74.

OZMEN, M., \& FIRIKCI, E. (2016). Gumruk Birligi Sonrasi Almanya ve Turkiye Arasindaki Ihracat Fonksiyonunun Ekonometrik Tahmini. Cukurova Universitesi Sosyal Bilimler Enstitusu Dergisi, 25(1), 25-140.

PERRON, P. (1989). The Great Crash, The Oil Price Shock, And The Unit Root Hypothesis. The Econometric Society, 57(6), 1361-1401.

ŞAT SEZGIN, A. (2017). Hazır Giyim Sektörü. Türkiye Is Bankası. https://ekonomi.isbank.com.tr/UserFiles/pdf/sr201705 hazirgiyim.pdf, date of access: 27.05.2018.

SIMS, C. A. (1980). Macroeconomics and Reality. The Econometric Society, 48(1), 1 48.

TODA, H.Y., \& YAMANOTO, T. (1995). Statistical Inference in Vector Autoregressions with Possibly Integrated Processes. Journal of Econometrics, 66(1-2), 225-250.

TRADE MAP (2017). International Trade Centre, https://www.trademap.org/Index.aspx, date of access: 27.05.2018.

TUIK (2017). Dis Ticaret Istatistikleri. http://www.tuik.gov.tr, date of access: 27.05.2018.

URAGEM (2016). Orme Konfeksiyon Sektorunun Rekabet Gucunun Artirilmasi Uluslararasi Rekabetciligin Gelistirilmesi Projesi, Ankara.

ZENGIN, E. (2015). Turkiye ve Rusya Federasyonu Ticari lliskileri. Avrasya Incelemeleri Dergisi (AVID), 4(1), 61-103. 